\title{
"I feel that our house is the future as well as the past": Architecture, monumentality and form in the modernist novel
}

\author{
Harrington Weihl
}

Follow this and additional works at: https://researchrepository.wvu.edu/etd

\section{Recommended Citation}

Weihl, Harrington, "'I feel that our house is the future as well as the past": Architecture, monumentality and form in the modernist novel" (2014). Graduate Theses, Dissertations, and Problem Reports. 7355.

https://researchrepository.wvu.edu/etd/7355

This Thesis is protected by copyright and/or related rights. It has been brought to you by the The Research Repository @ WVU with permission from the rights-holder(s). You are free to use this Thesis in any way that is permitted by the copyright and related rights legislation that applies to your use. For other uses you must obtain permission from the rights-holder(s) directly, unless additional rights are indicated by a Creative Commons license in the record and/ or on the work itself. This Thesis has been accepted for inclusion in WVU Graduate Theses, Dissertations, and Problem Reports collection by an authorized administrator of The Research Repository @ WVU. For more information, please contact researchrepository@mail.wvu.edu. 
"I feel that our house is the future as well as the past": Architecture, Monumentality and Form in the Modernist Novel

\title{
Harrington Weihl
}

\author{
Thesis submitted \\ to the Eberly College of Arts and Sciences \\ at West Virginia University \\ in partial fulfillment of the requirements for the degree of \\ Master of Arts in \\ English
}

Lisa Weihman, Ph.D., Chair

Sandy Baldwin, Ph.D.

Marilyn Francus, Ph.D.

Department of English

Morgantown, West Virginia

2014

Keywords: Modernism, Novel, Monument, Architecture, Forster

Copyright 2014 Harrington Weihl 
All rights reserved

INFORMATION TO ALL USERS

The quality of this reproduction is dependent upon the quality of the copy submitted.

In the unlikely event that the author did not send a complete manuscript and there are missing pages, these will be noted. Also, if material had to be removed, a note will indicate the deletion.

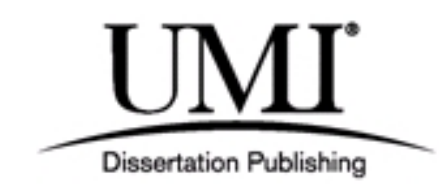

UMI 1554878

Published by ProQuest LLC (2014). Copyright in the Dissertation held by the Author.

Microform Edition () ProQuest LLC.

All rights reserved. This work is protected against unauthorized copying under Title 17, United States Code

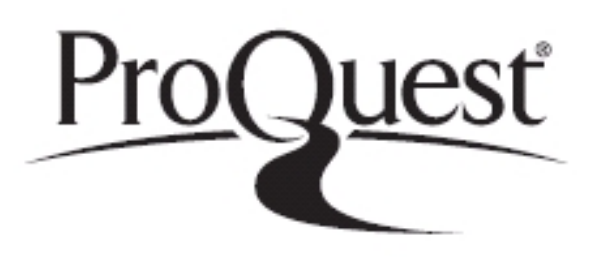

ProQuest LLC.

789 East Eisenhower Parkway

P.O. Box 1346

Ann Arbor, MI 48106 - 1346 


\section{ABSTRACT \\ "I feel that our house is the future as well as the past": Architecture, Monumentality and Form in the Modernist Novel Harrington Weihl}

Questions of how literary modernism and literary realism can be distinguished from one another, particularly in the transitional period at the beginning of the twentieth century, are central concerns in the study of literature. I argue here that in E.M. Forster's 1913 novel Howards End, the 'monumentality' of the titular house is the key to its inclusion in the modernist canon. This monumentality is incomplete, I claim, and as such formally replicates the impossibility of comprehending or representing modern life. I conclude with a similar reading of Elizabeth Bowen's 1929 novel The Last September in order to demonstrate that this spatial dynamic of monumentality, which I posit as what I call a 'mediating texture' in the modernist novel, obtains beyond the confines of Forster's novel. 


\section{Introduction: Monumental Modernisms}

In her article "Definitional Excursions: The Meanings of

Modern/Modernity/Modernism" Susan Stanford Friedman details the fraught usage of the terms modernity and modernism, with the latter in particular being problematic in that it "means not just different things, but precisely opposite things" (494). She explores the alignment of modernism with both industrial regimentation and the chaos exemplified by total war and urban life and comes to the conclusion that "[o]rder and disruption are symbiotically necessary to each other for each to have its definitive meaning" (510). Friedman is not alone in this assessment: Marshall Berman develops a similar configuration in relation to Marx, who always wavered between "the 'solid' and . . . 'melting' visions of modern life" (90). Each assessment of modernism asserts its own totalizing conceptualization. 'Modernism,' then, could be understood as a 'point de capiton' or 'quilting point' where multiple and contradictory terms are, according to infamous Lacanian provocateur Slavoj Zizek, "structured into a unified field through the intervention of a certain 'nodal point' ... which 'quilts' them, stops their sliding and fixes their meaning" (95). The monument, according to Lefebvre, plays a similar role within a spatial and social framework instead of a linguistic one. The sociospatial "texture is made up of a usually rather large space covered by networks or webs; monuments constitute the strong points, nexuses or anchors of such webs" (222). We could conclude from here that, in the most basic terms, Modernism can be understood to be properly monumental in that it unifies and determines the fabric made up of the terms that surround it. A sort of metonymic chain can be deduced from 
here, wherein the monumentality of modernism aligns with the monumenality of the modernist novel (Howards End) which then aligns with the monumental house in the novel itself.

The metonymic chain reaches its end, of course, in the 'reality' that it attempts to represent, which in Forster's case (and the case of the modernists in general), is a reality caught in the grips of a mechanization and modernization that renders it increasingly unrepresentable. In the broadest terms, monumentality could then be understood as a 'mediating texture' that negotiates between literary form and the reality it seeks to relate. The inevitable and necessary failure of this mediation is, as we will see, not a challenge to the fidelity of the modernist novel specifically Howards End - to modern life, but rather the secret to its success. I argue that the 'monumental failure' of Howards End in Howards End sets the tone for how the novel successfully grapples with modernity in a properly modernist fashion. I conclude by briefly reapplying the reading performed on Howards End to Elizabeth Bowen's later modernist novel The Last September in order to demonstrate how the recourse to architectural form in modernism works even when accompanied by formal experimentation to tie together different mediating textures.

\section{Howards End: Forster's 'Recourse to Form'}

E.M. Forster opens his 1910 novel Howards End with letters, remarking that "One may as well begin with Helen's letters to her sister" (5). The initial resignation to the epistolary form (which persists for only two relatively short letters) quickly foregrounds Howards End's uncertain position on the continuum of the novel's generic evolution. Neither experimental nor 
rigorously realist, Howards End seems to reside in the indeterminate space between the modernist and the Victorian novel - indeed, Fredric Jameson calls Forster "at best a closet modernist" (159). Nevertheless, Forster's work has often been read by critics as demanding inclusion in the modernist canon. ${ }^{1}$ Howards End, I contend, practices a limited modernism that is rooted in the very gap between its traditional form and its modern content that renders it so difficult to characterize. The discord between form and content is the locus around which the symbolic economy of the novel is organized. This economy is dominated, of course, by the titular house, Howards End. The novel and the house overlap within the same signifier, and the letters that open the novel take up a metonymic relationship with the house (and thus the novel) in that they take the form of writing about architecture. Helen responds to her sister, an absent interlocutor, by launching into a lengthy description of the architectural and spatial make-up of the eponymous house: "From hall you go right or left into a dining-room or drawing-room ... there's a very big wych-elm— to the left as you look up—leaning a little over the house, and standing on the boundary between the garden and meadow" (5). The house and its environs are described in terms of how they determine the motions of everyday life and the definitions of space; instead of being confirmed, however, this correlation is complicated and ultimately undermined as the novel progresses.

\footnotetext{
${ }^{1}$ These arguments generally ignore broader considerations of the relationship between modernity and modernism in favor of smaller-scale discussions of formal experimentation or modernist coteries. David Medalie's book E.M. Forster's Modernism makes a nuanced argument for Forster's classification as a modernist based on his subtle innovations that are at once acts of formal radicalism and notes of mourning for the traditional forms of the past. Forster features heavily in S.P. Rosenbaum's history Edwardian Bloomsbury mostly for his social and academic connections, but most significantly for his rejection of idealism. This rejection is significant in my argument, but more as a component of the larger discussion than as an end in itself.
} 
Howards End is often understood as a novel that is primarily concerned with place by virtue of its title alone; the title also marks the English home as the novel's definitive 'place.' Critics have often taken the lead from the title: while as Jon Hegglund claims, "[e]ven the most casual reader of Howards End cannot fail to notice the centrality of houses in the novel "(401), rigorous readers of the novel have also focused on the symbolic centrality of the house. ${ }^{2}$ Beyond the walls of the house, Jason Finch has identified the persistent attention that critics have paid to "the spirit of a place, the genius loci" in Forster's work, which absorbs the house itself into a broader, though still localized, consideration of place and being (2). Additionally, Howards End has also been included in notable assessments of the significance of the colonial in modernism; Jed Esty best sums up this approach in claiming that for Forster "metropolitan perception subsumes the lost value of territorial coherence while registering the epistemological privilege associated with modernity's borderless spaces" (28). In this line of argument - which originates with Fredric Jameson - the unrepresentable, but economically necessary colonial spaces can only be articulated in a discourse that opposes the 'lost' totality of the premodern with the chaotic totality of the metropolis. Here, I will respond to the dominant readings of Howards End by reconciling the readings of the novel that focus on the home itself and those that center around the colonial and domestic/metropolitan divide. As I will show, Howards End tries and fails to serve as the 'monumental' English space that Forster sets it up to be, partially due to its status as a pastiche that attempts to pass as an "authentic" English home.

\footnotetext{
${ }^{2}$ This is best illustrated by Trilling's claim that "the plot of Howards End is about the rights of property, about a destroyed will-and-testament and rightful and wrongful heirs. It asks the question, 'Who shall inherit England?'” (118), and Hegglund's assertion that "literary critics have agreed that Howards End symbolizes England throughout the novel" (402).
} 
Furthermore, in contrast with the house, colonial space in the novel can only haunt the margins of the text, and while definitively different from the monumental architecture of the home, is absent in a way that emphasizes the novel's incomplete spatial representation of the English nation. This reconsideration of Forster's emblem of quintessential English identity as a failed monumental space will not cut it off entirely from its semiotic link to England. Rather, it will open up space for a discussion of how national identity is undermined by the processes that produce it in a replication of the flows and forces of capital, imperialism and modernity that, I will argue, comprises the novel's modernism. This occurs in an historically specific way: the failure of the house as a monument is not, as we will see, straightforward and complete, and in fact takes the form of a transformative success that mirrors the aesthetic success of the novel, particularly in the way that the establishment of an emergent new monumentality mirrors Forster's foray into the emerging aesthetics of modernism. To move forward, then, it's important to establish what a 'monument' is in this context.

In The Production of Space, Henri Lefebvre defines what he calls 'monumental space' as being "the metaphorical and quasi-metaphysical underpinning of a society" (225). He does not accept the straightforward linguistic signification of monumental space, insisting instead that "semiological categorization (codifying) and symbolic explanations must be restrained" (221). As an alternative, he suggests that their "texture" is made up of three parts: first affective, lived experience akin to the spoken word, second perceived sociopolitical signification, and third at the level of the conceived, where the monument shapes both those who enter it and the society that surrounds it into a collection of subjects that comprise a consensus (222). This third element 
in particular is important in our consideration of Howards End, as Forster makes the failure of the house most clear in its inability to serve as the definitive social space in turn-of-the-century Britain in the terms that are set out for it. The emphasis on genius loci in Forster criticism aligns with conceived monumentality in that the materiality of the monument is part of a larger, immaterial ideological framework that imposes an ineffable field of power and influence that could be construed as spiritual. ${ }^{3}$ The level of conceived monumentality allows us to understand the house itself in the center / periphery configuration that Jameson advances. Of course, the social space of England is different from the social spaces of the colonies: the question of whether or not (and if so, how) a monument could determine, or at least relate to social spaces of the both the center and the periphery is one of the central questions of this thesis.

I'm drawing heavily on Fredric Jameson's reading of Howards End in my approach; for Jameson, empire gives the novel its "period designation" and is the "symptom" it is unable to contain - it is the unrepresentable kernel that the novel attempts to symbolically resolve through its engagement with infinity (162). Infinity in modernism here is inevitably spatial: Jon Hegglund identifies in modernism, and particularly in Howards End the trend of "'imagination becoming geographic' ... a kind of transformative expansion, one that opens up a world much larger than the situated view from the hilltops of southern England" (8). I argue for a different sort of (still spatial) symptom in Howards End - it is the house itself that cannot be represented or understood in the terms of monumentality that Forster lays out for it. The house is symptomal

\footnotetext{
${ }^{3}$ Lefebvre draws heavily on religious spaces in his explication of monumentality. Similarly, the term genius loci originated as a term for the "spirit" (or god associated) with religious and spiritual locations in the ancient Roman religion ("genius loci") We could understand monumentality in Howards End as a materialist reformulation of this same broad concept 'spirit'.
} 
insofar as its absence (which is a direct consequence of modern life) is the constitutive core of the novel's representational and symbolic economy. The house's monumental absence - it is positioned as a monument in the text without ever filling that role - is both covered and emphasized by its centrality in the novel. As such, the house is masked by the discourse within the novel just as the absence of an authentic core of the house is covered by the stylized, aesthetic affectations of the house. Similarly, the novel contains a masked ideological absence: David Bradshaw asserts that the novel "spotlights not the sturdiness of Forster's liberal values, but their relative frailty" (171); a novel that impels its readers to 'only connect' calls into question and undermines the sufficiency of connection. Absence as such - ideological, colonial, monumental - is central to my argument here, as the modernism of the novel rests precisely in its engagement with the absence of an appropriate form to deal with modernity.

Engaging with 'flux' - identified as a key element of the novel by both Andrew Thacker and Jason Finch - in Howards End will help us better understand monumentality and its relationship to 'form' in the novel. For Finch, London is 'in flux. It is grey in colour and restless. Paradoxically, it is both alive and inhuman, but neither animal nor monstrous" (262). Thacker similarly identifies London as the site of flux which - like the colonial for Jameson - is unrepresentable. Forster, for Thacker, is unable to work out "how London may be integrated into literature" (51) as he and the characters in the novel are "unable to keep up to speed with its ceaseless reshaping ... it exists 'beyond everything', unable to enter fully into representation" (51). It is this chaotic resistance to representation that Thacker calls 'flux,' and it has a differential relationship with the novel's form: "Form stands as the binary opposite to flux, and the novel is 
aware of a need for a modernist form able to register this incessant movement" (52). Thacker registers this discord as a "gap" Forster is "unable to bridge" (53), but I argue that, on the contrary, Howards End is conscious of this gap and bridges it successfully by means of a recourse to 'form' itself - form here being the monumental form of the titular house and the other architectural spaces in the novel. The novel recapitulates the gap between form and flux in the gap between the monument - pure form, a deterministic structure - and the modern life that it is meant to both crystallize and determine. Forster's success, then, is contingent on the gap that Thacker identifies insofar as the insufficiency of literary form emphasizes the insufficient monumental forms that comprise the novel's content.

\section{House as Monument}

The failed monumentality of the architectural forms in the novel appears initially to be rather straightforward: how can houses (ostensibly private spaces) and cathedrals (ostensibly public) be understood as equivalent, or at least analogous, spaces? The key to such a reading of the failure of houses as monuments in Howards End would be, consequently, that cathedrals practice a different sort of monumentality than houses, which themselves may not be properly monumental. Such a distinction does obtain here, in fact, but it does not preclude the existence of the monumental house. Lefebvre in The Production of Space identifies in modern life a breakdown in the dialectic between buildings and monuments: whereas in premodern periods buildings were the physical spaces that held the social position of monuments when consensus about social practice coalesced around them, modern buildings are constantly in opposition with 
monuments, "as everyday life is to festival, products to works, lived experience to the merely perceived, concrete to stone" (223). The chaos instigated by the suspension of the monumental, according to Lefebvre, necessitates that "buildings and dwelling places [are] dressed up in monumental signs: first in their facades, and later their interiors" as exemplified by the "erotic life" suggested by the "socialization" (via hosting spaces, bars and so on) of the home (223). Such a configuration, he claims, is supplemented by an inverted process - the privatization of the commons. In the theorization of the monument via the building, there then exists a clear divide between public and private spaces wherein the two are distinct yet simultaneously consubstantial.

For Lefebvre, however, it is precisely in this crossover between the two that the dialectical relationship between building and monument breaks down in modern life, which is characterized by the dialectic having ground to a halt, taking the form of "a stagnant opposition whose poles at first confront one another 'face to face', then relapse into muddle and confusion" (223). The confusion and intermixing surrounding buildings and monuments is replicated, necessarily, by the categories of public and private dissolving into one another. The dialectic of public and private is defined, differentially, by “intermediate spaces - for arteries, transitional areas, and places of business" (155). The crossover of public and private is, in itself, constitutive of the two categories and as such implies their complete reliance on one another for their mutual coexistence. The privatization of the public and the socialization of the private that Lefebvre identifies in modern space (as a consequence of the movements of capital) thus presents us with a means by which we can apprehend the house, a private space, as monumental. The point of 
intersection between the monument and private space in modern life - the incorporation of the 'signs' of monumentality - endow it with the capacity to determine both public and private life. Life itself, "the level of the body" is, as Lefebvre asserts, "transformed into a 'property' of monumental space" (224) and as such the incorporation of monumental signs into a house such as Howards End reifies the lives carried out within it as conditions of its monumentality. Helen illustrates this fact when writing from Howards End at the beginning of the novel, expressing her her fascination and amusement with the Wilcoxes, remarking that "it really does seem not life but a play, and it did amuse me enormously to watch" them go about their lives (6). The monumentality of the house is established retroactively in Helen's observation of a house - and a family - that defies her expectations.

Lefebvre insists on the fact that the monument can contain both the public and the private: "Monumental space permits a continual back-and-forth between the private speech of ordinary conversations and the public speech of discourses, lectures, sermons, rallying-cries, and all theatrical forms of utterance" (224). Helen's remarks, as we've just seen, attest to her apprehension of a theatrical element in the lives of the Wilcoxes within the walls of Howards End. The eponymous house is not the sole monumental house in the novel, of course; as Margaret has the unsettling realization that their lease on Wickham Place is expiring, she overhears Helen "down in the dining-room preparing a speech about political economy. At times her voice could be heard declaiming through the floor" (81). At a moment of very real crisis over the ownership and future inhabitants of one of the novel's foremost monumental houses (in a microcosmic preenactment of the crisis to come over Howards End), we find it filled with public 
discourse. The point where its private element - its basic function as a shelter - is called into question is the point where public speech is most pronounced within its walls. It would be incorrect to read this as an encroachment of the public on the private, a penetration of private life by public life when it is at its most vulnerable; instead, the monumentality of Wickham Place is reasserted by the scene that Helen relates to Margaret wherein, when practicing her speech, a lower-class woman barged into the house asserting to Helen that "I want my husband, what I have reason to believe is here" (83). Despite Helen's success in talking the woman down from her anger, Margaret worries that without the safety of Wickham Place, "her own little flock might be moving into turmoil and squalor, into nearer contact with such episodes as these" (84). The intrusion and penetration of the monumental space of Wickham Place by the public, and specifically by a member of a feared, Other public, illustrates the incomplete and compromised monumentality of the house. ${ }^{4}$ It does so in that despite its pretense to property, the signs of monumentality that it bares - as an English (though part-German) Home in a part of London where they're becoming ever more rare - mark it as a space suffused with liberal, public discourses about class (both Helen and Margaret are here in the midst of preparing speeches for a “discussion group" that regularly addresses social issues (84)) due simply to its monumental presence within the city.

The distinction between house and home recapitulates the public / private division we've negotiated above. Lefebvre writes that, when the social fabric is broken and monumentality is in

$4 \quad$ The fact that Wickham Place is leased and not owned by the half-German Schlegels only magnifies the extent to which it is compromised. As we see, Forster continually heaps on the markers of monumenality while simultaneously undermining them. 
crisis, "the building and its functions come into their own; by the same token, housing comes to prevail over residence within that city or amidst that people" (222, emphasis his). We can take 'residence' in Lefebvre to be roughly analogous to the concept of 'home' with its ties to the land and a specific sense of belonging. Housing, then, is residence when residence takes place within buildings. This suggests, inversely, that residence as such takes place in the opposite of the building: the monument. In a nation where (often rural) domesticity and nationalism are so inexorably intertwined as England, such a situation is not surprising. The monumental residence is the premodern abode of the aristocracy, and precedes " $[\mathrm{b}]$ oth privacy and facade, which will come only with the advent of the bourgeoisie and the bourgeoisification of the nobility" (314). We find in the Wilcoxes and Schlegels a bourgeois relationship to lived space, at least initially, when they move variably from house to house - "the Wilcoxes collect houses" (123), as Helen puts it - treating each as housing rather than residence. At the same time, however, this bourgeois stance is tempered by the aura of Howards End as a house; Helen, when pregnant and in an "imaginative state" as Margaret phrases it, rejects Henry Wilcox's offer of a hotel room, instead wanting to stay at Howards End, Wilcox is unable to understand her attachment and argues to Margaret that he

could understand it if it was her old home, because a home, or a house"-he changed the word, designedly; he had thought of a telling point-"because a house in which one has once lived becomes in a sort of way sacred, I don't know why. Associations and so on. Now Helen has no associations with Howards End, though I and Charles and Evie have. I do not see why she wants to stay the night there. She will only catch cold." (217) 
The appeal of Howards End - a perverse appeal, in Henry's mind - is such that it transcends commonplaces about the difference between house and home and instead takes on an aura of its own that is distinct from the other houses that the Wilcoxes inhabit - seven in total - over the course of the novel. It is precisely this aura that positions Howards End as a monument insofar as it is more 'work' than 'product' (to use Lefebvre's phrasing). Walter Benjamin, of course, defines the modern loss of aura due to the mechanical reproduction of artworks as a result of the fact that "the technique of reproduction detaches the reproduced object from the domain of tradition" (221). We are not privileged to a description of the production of Howards End, yet as Lefevbre says, the spatial "actions of social practice are expressible but not explicable through discourse; they are, precisely, acted - and not read"' (222, emphasis his). The monument, then, is that which is treated as a monument in such a way that it is endowed with an aura purely in being treated as having an aura; as Benjamin establishes, aura is drawn from the original ritual use value attributed to an object (224), and the establishment of social and spatial norms to which people adhere is the use value of the monumental space. All this said, however, this conception of monumentality could be correctly understood as being compromised and incomplete in modernity. It is in this very incompleteness - borne out by the functions of Howards End and Wickham Place - that we are able to locate the operative gap in modern monumentality that Howards End confronts. 
Weihl 14

\section{Cathedrals \& Houses: Monuments in Howards End}

The novel proper opens with a discussion between Helen and Margaret Schlegel that introduces an ideal of monumentality to which the houses in the rest of the novel will continually aspire but never succeed in achieving. Margaret tells the story of first meeting the Wilcoxes while traveling in Germany: "Helen and I had got it into our heads that there was a grand old cathedral at Speyer - the Archbishop of Speyer was one of those seven electors - you know 'Speyer, Maintz, and Koln.' Those three sees once commanded the Rhine Valley and got it the name of Priest Street" (Forster 7-8). Lefebvre acknowledges the monumental nature of cathedrals in general as illustrative of monumentality: "the cathedral's monumental space necessarily entails its supplying answers to all the questions that assail anyone who crosses the threshold ... they will partake of an ideology; they will contemplate and decipher the symbols around them; and they will thus, on the basis of their own bodies, experience a total being in a total space" (221). The success of the cathedral at Speyer as a monument extends beyond its walls; the Rhine valley loses both its ideological neutrality and its actual geography. In Germany, the rule of the Catholic Church in centuries past saw the Rhine Valley transformed into a boulevard, an image that demonstrates the way in which the cathedral is able to establish a nation (the Holy Roman Empire) around it by creating a consensus over cultural and social practice.

By the time the Schlegels visit it, however, the cathedral that christened Priest Street, so emphasized by Forster, is already a relic of the past relative to the present of the novel. Indeed, as Margaret remarks, "the cathedral had been ruined, absolutely ruined, by restoration; not an inch left of the original structure" (8). In place of the original, the tourists find what amounts to 
nothing more than a modern simulacrum of what was once one of the seats of power that transformed the Rhine. The cathedral has lost its monumentality, rendering any attempt to "restore" it futile. Lefebvre is helpful again here, as he says "every mode of production produces a space ... its own space" (31) and, accordingly, "new social relationships call for new space, and vice versa" (59). This is the central problem presented by the "restored" cathedral - however dutifully reproduced it is materially, it lacks the congruence with the novel's contemporary social life that a true monument would have. It is at this point that authenticity can be brought, hesitantly, into the discussion, if we accept it to correspond only to the fit between a space and the society that produces it. The failed monumentality of the inauthentic cathedral sounds a note that reverberates through the rest of the novel, quietly calling into question the authenticity and monumentality of Howards End and the English house. The Schlegels' enlightened desire to visit a monument of historical and religious sanctity is foiled by the doomed attempts of the modern Germans to restore it to its pristine original condition and perpetuate its role as a monument in German society. In noting this interference, the Schlegels exhibit the sort of cosmopolitan, idealist critical rigor that, partially due to this initial example, Forster leads the reader to expect from them. Nevertheless, they do not manage to maintain the same vigilance upon their return to England, as Forster allows the mists of nationalism to descend and obscure the critical eye of the Schlegels and, without sufficient resistance, the reader.

Howards End and the other houses in the novel attempt to establish England as a national space in a way similar to the process whereby the cathedral successfully turned the Rhine into Priest Street, but they never succeed. Forster initially positions Howards End and the other 
domestic spaces in the novel as original and authentic. The London home of the Schlegels is introduced by Forster in a manner that differs starkly from description of the cathedral at Speyer: “...a lofty promontory of buildings separated it from the main thoroughfare. One had the sense of a backwater, or rather of an estuary, whose waters flowed in from the invisible sea, and ebbed into a profound silence while the waves without were still beating” (8). The Rhine's transformation into Priest Street is inverted here; the street on which Wickham Place rests becomes a body of water, a stale backwater contrasted with the sea of the city. This reversal mirrors the larger reversal of the way in which Forster positions Wickham Place historically. We are told that

Though the promontory consisted of flats - expensive, with cavernous entrance halls, full of concierges and palms - it fulfilled its purpose, and gained for the older houses opposite a certain measure of peace. These, too, would be swept away in time, and another promontory would rise upon their site, as humanity piled itself higher and higher on the precious soil of London. (8)

Instead of a restored and ruined cathedral, Wickham Place is positioned as a monumental seat of authenticity juxtaposed with the gaudy promontories. Accordingly, in keeping with the inherent instability of capital and modernity (and much to the horror of its inhabitants), the house will eventually be replaced, for the sake of profit, by towers of flats that, while fulfilling their purpose as living quarters, cannot successfully replicate the seemingly authentic English home. The opposition with Wickham Place is not complete, however - like Austen's Wickham, the house is to an extent counterfeit, leased by half-German occupants, masquerading as an English 
monument in a fraught space where such a monumentality is under threat and as such is emphasized differentially.

What are we to make, then, of the fact that Forster presents us with the restored and desecrated cathedral and the ostensibly authentic home side-by-side so early in the novel? As shown above, they are each subjected to transformations that flow in two opposite directions: the authentic monument of the cathedral, now replaced for all intents and purposes, originally instigated the river's conversion into a street, while Wickham Place does the opposite, transforming a street into an estuary. The means by which this latter transformation takes place establish the way that the house operates as a space that contains the confluence of social and market spaces. Without the promontory, that modern contagion protecting Wickham Place from the noise of the city, the image of the estuary disintegrates. Consequently, while Forster would seem, superficially at least, to be establishing the sanctity of the English home as equivalent to the sanctity of the cathedral, the reality is more complicated. The cathedral begat Priest Street as its monumentality was a function of the hegemony of the Catholic Church during the Holy Roman Empire (7), and the decay of that hegemony coincides with a change in the nature of the Rhine Valley (which, as Forster leaves unmentioned, perhaps intentionally, is a center of industrial power in the novel's present) and with the decline of the structural integrity of the building itself. Alternatively, Wickham Place requires the presence of the industrial high-rises in order to serve as the lynchpin of the metaphor. Unlike the cathedral, an original and definitive monument that transformed its surroundings and produced its attendant social forms, Wickham Place only appears to come to symbolic fruition in the presence of its negation. It is only able to 
signify differentially under the specter of its own demise, which is to say that it is not a monument but rather part of the social and cultural landscape determined by the high-rises that surround it.

\section{House as Failed Monument}

What justifies investing so much interpretive weight in this opening passage? As the first house introduced in a novel so preoccupied with houses, Wickham Place signals the problematic and complicated way in which houses fail to attain traditional monumentality; the house is not the premodern monument that dominates and determines the space around it, but rather is subject to being determined by its surroundings, specifically those surroundings that signal its obsolescence. Even though it seems to sit outside of London's urban sprawl, Howards End is in fact part of the same social and cultural fabric, and its failure as a monument further explicates the foundations of Forster's modernity. While, as noted above, Howards End is generally accepted by critics to stand for England, the way in which Wickham Place is depicted suggests that English houses are not the monumental social and cultural spaces that the novel outwardly portrays them to be. Indeed, an examination at Howards End itself will show this to be the case. The house and its environs contain the tension between modernization and 'tradition' that the novel takes up more broadly. The wych-elm that hangs over the house and separates the garden and the meadow has "pigs' teeth stuck into the trunk ... The country people put them in long ago, and they think that if they chew a piece of the bark, it will cure the toothache" (54). Mrs. Wilcox goes on to claim that the bark from the tree "would cure anything-once. Certainly I 
remember cases_-you see I lived at Howards End long, long before Mr. Wilcox knew it." This claim raises the questions of who, exactly, the country people were: with their "festering superstition" (54), they're far removed from the 'enlightened' England of the Schlegels and Wilcoxes. To reinforce that fact, Henry Wilcox is revealed later in the novel to have worked tirelessly to update the house. In fact, he "had saved it; without fine feelings or deep insight, but he had saved it" from the onrushing obsolescence of the small family farm, and Mrs. Wilcox "loved him for it" (148). The modernization process was completed with more resistance later, with the construction, by Henry and Charles of a "garage! With what difficulty had they persuaded her to yield to them the paddock for it - the paddock she loved more dearly than the garden itself!" (69). Nevertheless, in Margaret's eyes, the modernized farmhouse "was English, and the wych-elm that she saw from the window was an English tree" (148). The tree and the house, one suffused with festering superstition and the other painstakingly modernized, are contained by 'English' as a category in Margaret's mind and in the novel as a whole, fostering a tension in the term that demands resolution.

A path to resolution could lie in the way in which the house's 'modernized' state implicitly constructs the original house as premodern, and thus on par with the mystical tree, with only the new-found capitalist impulse of Henry Wilcox having spoiled it, just as it spoils the country at large. A closer look, however, will reveal that the representation of England is not so simple. In the novel's first line, Helen describes Howards End as not "what we expected. It is old and little, and altogether delightful - red brick" (5). Hegglund's historical perspective is helpful here: "Forster constructs this house as a representation using the materials of a specifically Edwardian 
architectural fashion that fetishized an idea of 'old England' through its skillful simulation of past styles" (404). This concept of 'old England' is what the novel encourages us to believe to be the metaphysical underpinning of the nation, with Howards End as its monument. Attuned to the ruination that restoration can bring to formerly authentic spaces, the Schlegels expect "all gables and wiggles, [a] garden all gamboge-colored paths ... simply because we associate [the Wilcoxes] with expensive hotels" (Forster 5). The Wilcoxes, defying expectation, reject the nouveau-riche trappings of faux aristocracy for what the Schlegels believe to be a modest and somehow 'original' English home. The unmasking of the English home in the novel does not occur through any of the characters, however; indeed, Hegglund's knowledge of Edwardian architectural style, while helpful, is not even entirely necessary to understand, broadly, the historical genesis of Howards End. After the Schlegels and Wilcoxes are united at the end of the novel, Helen warns that "'All the same, London's creeping.' She pointed over the meadow - over eight or nine meadows, but at the end of them was a red rust" (240). The urbanity that slouches toward Howards End is signified by red brick dust - the same contagion that appeared in Hertfordshire during the construction of Howards End a century or so earlier, when the burgeoning bourgeoisie had their taste for authentic Englishness sated by delightful red brick country homes.

The fact that the novel's centerpiece, the failed monument to early 20th Century English identity, is itself an early modern pastiche of essential 'Englishness' drags the English home out of the mystical past and 'down' to the level of the London tenement, right into the modernity that 
Forster depicts in the novel. ${ }^{5}$ This modernity consists of uneven urban and social development, which leads to flux and instability. Spatially, this instability is most clearly evinced in the block of flats to which Leonard Bast returns:

A block of flats, constructed with extreme cheapness, towered on either hand. Farther down the road two more blocks were being built, and beyond these an old house was being demolished to accommodate another pair. It was the kind of scene that may be observed all over London, whatever the locality - bricks and mortar rising and falling with the restlessness of the water in a fountain, as the city receives more and more men upon her soil. Camelia Road would soon stand out like a fortress, and command, for a little, an extensive view. Only for a little. Plans were out for the erection of flats in Magnolia Road also. And again a few years, and all the flats in either road might be pulled down, and new buildings, of a vastness at present unimaginable, might arise where they had fallen. (36)

Forster's ominous depiction of the perpetual state of tumult brought upon London by modernization and the accompanying refiguration and expansion of class boundaries (Leonard's petit-bourgeois status is often ignored: he is not a proletarian, but rather a clerk) carries with it a clear note of melancholy for the old houses lost as the city expands. Nevertheless, though Forster outwardly promotes the old houses as organic and natural by way of contrast - the new flats rise and fall restlessly like fountain water, a contrived, man-made alternative to the natural and

\footnotetext{
${ }^{5}$ Ian Baucom, in discussing the rise, in the 1980s, of nostalgia for the country house in England, claims that it had become fetishized, "a cultural artifact, a spectacular arrangement of built space, valued less for itself than for the absence or lack that it at once covers and names" (165). We could think of Forster as anticipating this nostalgia (and lack) and identifying their emergence in his own period.
} 
undisturbed estuary that encompasses Wickham Place, or the fertile freshwater of flowing rural rivers that Jason Finch has identified as carrying symbolic weight in the novel (262) - the old houses being demolished are composed of bricks and mortar, and fit into the continuum of urban construction and destruction that Forster establishes. Forster here most clearly acknowledges the relentless advance of capital as an inevitable doom, foreshadowing Helen's later remark that "[the advance of] London is only part of something else, I'm afraid. Life's going to be melted down, all over the world" (240). She and Forster echo Marx sixty years after the fact - "all that is solid melts into air, all that is holy is profaned."

Indeed, the fact that Marx predates their sentiment by over half a century is testament to the reality that Howards End itself is not the profaned sacred (unlike the cathedral, which is easily recognized as such) but instead something more closely aligned with the actual process of desecration itself, being a product of an earlier phase of modernization that is distinct from the organic (or more precisely, premodern) cathedral. It is important to note here that even in Forster's time, capitalism was a centuries-old mode of production, and the traditional did not always align with the premodern. Accordingly, the age of the house is not the sole index of its modernity: Forster estimated the age of his childhood home of Rooksnest House (on which Howards End was modeled) at 200 years or more (286) but nevertheless is sensitive to the “middle-class slant” it gave to his worldview (284). In All That is Solid Melts into Air, Marshall Berman asserts that in saying the holy has been profaned, "Marx is moving in the dimension of time, working to evoke an ongoing historical drama and trauma" (89). We find this historical drama in Howards End both in its progressive class politics and its nostalgic attitude toward the 
construction of England's past, ${ }^{6}$ and the temporal tension between the premodern and the traditional that the house embodies ${ }^{7}$ underlies these configurations. In a parallel formulation, however, it is simultaneously true that, in Lefebvrian terms, Marx is also moving in the dimension of space: the metaphysical undergirding of society - the spatial fabric that corresponds to the social fabric - is revolutionized perpetually by capital to the extent that the identification of architectural spaces such as the cathedral at Speyer or the Parthenon with social, cultural and political formations such as the Holy Roman Empire or Athens is no longer possible for Howards End with regard to England. The expanding urban landscape, subjected to repeated melting and reconfiguration will eventually subsume a pastoral landscape that is not its antithesis but rather the product of the preceding stage of capitalist creative destruction.

\footnotetext{
${ }^{6}$ Nostalgia and progressive policy are also in tension for Forster more broadly. Writing in 1946 in "The Challenge of Our Time" Forster expresses his angst over the effects of central planning (championed by fellow Cambridge Apostle John Maynard Keynes) and its capacity to destroy traditional lifeways and, crucially, living spaces: "a satellite town for 60,000 people is to be built. The people now living and working there are doomed; it is death in life for them and they move in a nightmare. The best agricultural land has been taken . . . the satellite town has finished them off as completely as it will obliderate the ancient and delicate scenery" (324). Forster concludes that the writer, artist or intellectual "ought to impose [an aesthetic] discipline on himself rather than accept one from outside" (325), a claim that elides the working-class populations affected by central planning in favor of the aesthetic sanctity of the countryside.

${ }^{7}$ It is worth noting that Rooksnest, in Forster's description, blurs the line between middle-class farmhouse and aristocratic estate: he writes that the "name Rooksnest was not an ordinary name of a house but the name of a hamlet consisting of us and the farm below. Mother when she came heard that the house was to be called 'Chisfield Villa' and nearly had a fit" (286). The spatial situation of the house is significant in that the house and the surrounding have a metonymic relationship that recalls aristocratic links between a manor house and its estate. At the same time, however, Forster's mother's aversion to the forced aristocratic airs of the moniker 'Chisfield Villa' changes the valence of the spatial configuration of Rooksnest revealingly in that it uncovers the tension between the aspirational ethics of the middle-class (at once traditional and necessarily revolutionary) and the lingering remnants of the aristocracy precisely in their orientation toward the past vis-a-vis architecture and space.
} 


\section{England: A Monumental Nation}

It follows from this that England, as an extension of its contradictory identification with the monumentality exemplified by homes such as Howards End and Wickham Place, has its own authenticity and sanctity called into question. A nation so inextricably tied to overseas trade and imperial markets is, like the houses that purport to embody it, unable to divorce itself from the market processes that appear to threaten its very existence. The modernity that Forster presents in the novel is tied at once to both the English imperial project and to stateless, cosmopolitan flows of capital. These distinct but interrelated realms of accumulation operate in tandem while nevertheless adhering to different logics. The same can be said for the two monumental houses in the novel; they can be set in opposition in revealing ways: the urban, cosmopolitan, half-German Schlegels reside at Wickham Place, where as we've seen monumentality has a different valence, as the house is an island within a foreign, metropolitan space. Howards End and the various country houses where the Wilcoxes reside are privileged by their rural settings, where the space surrounding them can more easily be defined. Nevertheless, whether urban or rural the house is the central symbol of the novel, and the fact that this symbolic role persists regardless of its context speaks to the compromised modern monumentality that Forster depicts - the houses, in being positioned as monuments face an imperative to exert influence over the spaces surrounding them, and regardless of their situation, the results are complicated and incomplete. This much is evident in the differential signification of Wickham Place as it sits in the shadows of the tenements that surround it. The equivalence of the metropolitan and the colonial that Jameson identifies (in a repetition of John Ruskin's claims a century earlier) is echoed here as the house 
and the city themselves are defined through opposition, in a replication of the opposition between nation and colony that, as Ian Baucom has argued, persisted throughout the modern period, wherein "the task of 'locating' English identity became ever more complex as England struggled to define the relationship between the national 'here' and the imperial 'there'" (37).

Baucom's locational logic can be extended to the relationship between Wickham Place and the urban wastes of London: as shown above, Forster puts forth Wickham Place and Howards End as monuments that fail in their correspondence to social practice while still appearing to stand for some essential Englishness. Jameson, as we've established, links the incomprehensibility of modernization to the radical otherness of colonial space; similarly, though, we get the same impression from Forster's contemporaries. Baucom explains that in English urban space,${ }^{8}$ Ruskin discerned an uncanny, "troubling vision of the imperial beyond" (62). It is instructive that Ruskin, who receives such a withering treatment from Forster as the object of Leonard Bast's petit-bourgeois admiration, nevertheless sets the tone of what Forster inherited in terms of an understanding of the relation (both material and symbolic) between empire and the metropolis. The passage from Ruskin that Bast, pitifully, seeks to imitate does not detail the colonial or the modern metropolitan, however. Instead, we find Ruskin "speaking to us from his gondola. 'Seven miles to the north of Venice the banks of sand which nearer the city rise little above the low-water mark attain by degrees a higher level . . raised here and there into shapeless mounds ... intercepted by narrow creeks of sea"” (38). Forster presents us with

\footnotetext{
8 "Ruskin, like many of his contemporaries, saw not a space of belonging and collection but a space of decomposition, not a comforting image of home, but a troubling vision of the imperial beyond, monuments to the domestic English past but intimations of its future identity as home to the lapsed empire's migrants" (62-3).
} 
Ruskin's indirect view of Venice, which is preoccupied entirely with its omnipresent tidal waters; the mercantilistic Venice of the Renaissance and the unsettling liquidity of capitalism are evoked in a manner that echoes the rising and falling waters of Edwardian London. The passage of Ruskin that follows, however, does not deliver on this suggestive alignment, as Ruskin is now in the city itself, asking readers to consider "what is very peculiar to this church-its luminousness" (38). Via Ruskin, Forster shifts abruptly from the murky mysteries of international capital to the illuminated monumentality of a Venetian cathedral. The preoccupation with monumentality that undergirds Forster's writing in the novel and the writings of Ruskin within the novel demonstrate how architectural spaces were sapped of their ability to determine social space in a truly monumental fashion once that social space was suffused with the invisible, imperial beyond, as in London and with the liquidity of capital, as in Venice. These two contagions are at once distinct from one another and inseparable, and in representing a Venetian capitalism that develops in the midst of monumental, old world cathedrals, Forster foregrounds the absence of monumentality in modern London, where the buildings themselves comprise the tides instead of standing as monuments.

This is not to say that London lacks a cathedral of its own: as Jason Finch notes, Forster places great symbolic weight on "St. Paul's Cathedral, [the] illusory beacon of hope in the city for Helen and Leonard which symbolizes Forster's floating, delusional London and which also appears on the logo of Leonard's employers the Porphyrion Insurance Company” (268). In his exploration of Forster's use of symbolism, David Medalie asserts that St. Paul's "both represents London and opposes it; it stands as an embodiment of the city and a countermanding 
presence ... [not] a monolith seen steadily and whole, but a nexus of divergent meanings" (88). We find here very clearly what I've come to call 'failed monumentality' in the form, crucially, of a cathedral. Indeed, the difference in this last cathedral, for Margaret, is that amid "echoes and whispers, inaudible songs, invisible mosaics, wet footmarks," it becomes clear that "Henry was the only hope. Henry was definite" (200). The embodiment of the colonial casts a deafening shadow over the total physical experience of the cathedral that Lefebvre identified as indicative of monumentality. The quintessential monument has been sapped of its deterministic force in favor of a representative of the incomprehensibly vast and dispersed empire that fuels the fires of urban development and the imagination of the nation. The national imaginary is equally preoccupied with the metropolis, often understanding it at some level as an extension of the colonies. Margaret when talking to Tibby draws equivalence between England's imperial project and the urban growth of London: "An Empire bores me, so far, but I can appreciate the heroism that builds it up. London bores me, but what thousands of splendid people are labouring to make London" (Forster 82). When crystallized together so clearly, the kindred spheres of production don't seem such an unnatural pairing. The difference between the two lies in how Forster foregrounds and satirizes Margaret's progressive, social-democratic idealism through her dismissal of the products of modernization and her embrace of the processes that produce them. She is unable to take even the standard liberal, progressive position on modernization; hers is a reversal of the common justification of modernity's brutal nature - "Yes, but look at what mankind is capable of!" - in that she is more enthusiastic for the creative-destructive grind of modernization than she is for "the triumphs of modern bourgeois technology and social 
organization" that Marx himself commended (Berman 93). There is no room in Margaret's figuration for colonized people; the violence of primitive accumulation in the colonies and the very real violence enacted on colonized populations is ignored in favor of those agents of "heroism" that comprise the colonizing force. Nevertheless, the labourers that are erecting London at the time are not subject to the same elision and instead are lionized alongside those who labor to expand the empire.

Again, the colonial project is shown to be related to but distinct from the project of urban development insofar as the latter is reliant on the colonized land and populations that are absent from Margaret's equation, and the novel as a whole. The colonial hangs in the background as an absent cause, as in Henry's office, where a map of Africa - “an abstraction without any aura of particularity" (Hegglund 59) - hangs “on which the whole continent appeared, looking like a whale marked out for blubber, and by its side was a door, shut, but Henry's voice came through it, dictating a 'strong' letter" (Forster 141). The dictations of the capitalist are removed from the image of the colonized continent just as the novel has overt depictions of colonialism stricken from it almost entirely. As Fredric Jameson explains, the "'imperial' function- the persons of the colonized — remains structurally occluded, and cannot but so remain, necessarily, as a result of the limits of the system, and the way in which internal national or metropolitan daily life is absolutely sundered from this other world henceforth in thrall to it" (163). Direct representations of colonial life are missing completely, and at times even the colonizers, namely the grown Paul, only appear as shades: when Paul returns from the colonies late in the novel, Margaret and Helen "turned and looked at [Howards End]. Their own memories coloured it for now ... Then 
Margaret said: 'Oh, take care-!' for something moved behind the window of the hall, and the door opened. 'The conclave's breaking at last. I'll go.' It was Paul.” (240). Paul, the second son of Henry who leaves for the colonies to seek his fortune in the opening scenes of the novel and returns as it closes embodies - precisely in his absence - a more immediate and uncanny ${ }^{9}$ relationship between the colonizers and the colonized, as he is only able to haunt the text, moving eerily behind the windows of a novel that attempts to neatly contain some essence of English identity, weighing like a nightmare on Forster's pastoral dream of Englishness.

The colonial is not solely an index of the English relationship to the metropolis ${ }^{10}-$ the English home, as Forster demonstrates, must be English in order to be a home, and must be a home in order to be English. After Oniton Grange is leased, Margaret asks Henry "'Where are we to live?' said Margaret, trying to laugh. 'I loved the place extraordinarily. Don't you believe in having a permanent home, Henry?' He assured her that she misunderstood him. It is home life that distinguishes us from the foreigner" (185). What could easily and understandably be read as a bigoted and imperialist quip by the novel's arch-capitalist can simultaneously be read as an affirmation of the nation-building power of houses such as Howards End, which construct the ideal of the nation just as surely as, when serving as homes, they construct the identities of their

\footnotetext{
${ }^{9}$ Homi Bhabha, in "Signs Taken For Wonders" discusses the centrality of mimicry, a "colonial doubling" (162) wherein both colonizer and colonized are hybridized to an extent. The subtlety of this process is characterized as "uncanny" (159) insofar as the doubling of both colonizing and colonized subjects produces a disturbed, haunted familiarity akin to what we find in Paul in Howards End.

${ }^{10}$ Peter Morey posits that Forster was conscious of the English "urge to self-dramatize" in relation to its colonies (255).
} 
occupants. ${ }^{11}$ It is not the actual practice of home life that distinguishes the Englishman from the Spaniard or the Barbadian, but rather the very possibility of the sort of home that Henry is talking about - such a home is too bound up in the ideal of the English nation to occur anywhere else. "The foreigner" is necessarily incapable of living the home life that Oniton, Wickham Place and Howards End seem to promise, as the presence of foreign bodies in the English home would (and subtly does, perhaps, via the Schlegels) put an end to its Englishness and, necessarily, its homeness; national identity and the national home are mutually constitutive concepts. Forster highlights this tension by staging the domestic drama of the novel around the arc of Margaret's acquisition of the house; it falls into cosmopolitan hands only when those hands have been thoroughly domesticated and demonstrated to be incapable of and unwilling to challenge or alter the imperialist-capitalist axis that dominates European society and culture.

\section{Idealism and Nostalgia}

Early in the novel, German expatriate and idealist Uncle Ernst decries the imperialist impulse in a debate with his "haughty nephew" while a young Margaret Schlegel and the reader listen in: "It is the vice of a vulgar mind to be thrilled by bigness, to think that a thousand square miles are a thousand times more wonderful than one square mile, and that a million square miles are almost the same as heaven" (23). Ernst, a veteran of the Franco-Prussian war, sees the agglomeration of spaces - in the forms of nations and empires - as detrimental to 'imagination.'

\footnotetext{
${ }^{11}$ In "The Invention of Everyday Life," Rita Felski links Lefebvre's 'everyday' to the home, and thus provides an insightful synthesis of "everyday life [which] does not convey a particular sense of space" (22) and home, which "in its very familiarity becomes a symbolic extension and confirmation of the self" (25).
} 
Having fled Germany disillusioned after the war, Ernst argues that the Germanic poets, philosophers and musicians "to whom Europe has listened for two hundred years" have disappeared "with the little courts that nurtured them - gone with Esterhaz and Weimar" (23-24). Of course, Uncle Ernst's sense of mourning ignores the similarities between the "little courts" and the massive empires that replaced them; the now-lost incubator of imagination at Weimar is nothing more than an underdeveloped species of the bureaucratic apparatus of the British Empire, and the continuity between enlightenment ideals and imperialism undermines Ernst's nostalgia. Ernst's beloved 'imagination' has a particularly cosmopolitan, continental character that sets it apart from England - Andrea Zemgulys argues convincingly that this distinction can be found in the spatial dynamics of Howards End. ${ }^{12}$ Indeed, in the Schlegel sisters we find the eventual domestication - in a national and in a gendered sense - of Forster's German idealists, the "paler and more respectable forms" of the stereotype of the German as at once barbaric and uncannily familiar (Jameson 156).

Ernst's nostalgia for pre-imperial Germany, a Germany without "colonies here and a Forward Policy there" (23) is situated as the influence for Margaret and Helen Schlegel's idealist

\footnotetext{
${ }^{12}$ In Modernism and the Locations of Literary Heritage, Zemgulys confronts modernism's "vexed relation to the past" (1) by way of a spatial reading of how pasts figure in modernist texts. When focusing on Howards End, she identifies the Chelsea Embankment in London as unique among the novel's representations of the city because its cosmopolitan "heritage had endowed Chelsea (and its riverfront area especially) with a marked sense of space" (111) that stands in stark opposition to the "more dismal scenes of a morphing and demonic city" (124) in the novel. Zemgulys's reading centers on a historical examination of the embankment, which is characterized in Howards End as possessing a "dignity that is rare in English cities ... There is something continental about the Chelsea Embankment ... an open space used rightly, a blessing more frequent in German than here" (Forster 120). For my purposes, it is important to note that the opposition between the embankment and the city itself is a product of the Schlegel's idealism, which is itself an ideology rooted in nostalgia for a past that never existed; in this way, their idealism bears a resemblance to the houses in the novel.
} 
cosmopolitanism later in the novel. Upon returning to Howards End after it comes into her possession, Margaret

recaptured the sense of space which the motor had tried to rob from her. She remembered again that ten square miles are not ten times as wonderful as one square mile, and that a thousand square miles are not practically the same as heaven. The phantom of bigness, which London encourages, was laid for ever when she paced from the hall at Howards End to its kitchen and heard the rains run this way and that where the watershed of the roof divided them. (145)

Margaret's everyday practices of domesticity allows her to exorcise the 'phantom of bigness' that so haunted her Uncle by suppressing and controlling the anxieties of modernity. Her opposing conceptions of the world - the ideal of the domestic-pastoral and the industrial-colonial that makes that ideal possible - are, like the rainwater on the roof, divided from one another by the house. Likewise, the cathartic, resistive ${ }^{13}$ spatial transit from the hall to the kitchen mirrors the psychological work of traversing the divide between the horrors and comforts brought on by modernity. Others have emphasized the house as a spatial emblem of psychic states, ${ }^{14}$ and the division of Margaret's psyche is a necessary component of the bourgeois subjectivity that

\footnotetext{
${ }^{13}$ Leonard Bast's nocturnal peregrination through London marks him as a character that, instead of traversing class boundaries as seems to be the case, actually uses physical movement to enact his petit-bourgeois class status; as Michel De Certeau notes in The Practice of Everyday Life, "[p]hysical moving about has the itinerant function of yesterday's or today's 'superstitions" which are the "local authorities" (106) that modernity seeks to eliminate in its drive for totalization. Leonard uses movement to open up space for resistance in the city itself while seeking the refined idealism that he sees as standing in opposition to his everyday experience. Similarly, Margaret uses physical movement in the house to open up that space and resist "the phantom of bigness."

${ }^{14}$ In his book on the phenomenology of intimate spaces The Poetics of Space, Gaston Bachelard asserts that "[a]11 great, simple images reveal a psychic state. The house, even more than the landscape, is a 'psychic state'" (72).
} 
accompanies Margaret's class position. ${ }^{15}$ The water, which we've noted to be symbolic of the flux of capital and urban modernity, is controlled and diverted by the house, recalling the way in which the house itself serves as a crystallization of capitalism and modern development, a pastiche that is retroactively imbued with nostalgia. The fate that Margaret and her sister meet in the novel - as owners and tenants of Howards End - confirms again that like the space of the house itself, their cosmopolitan, idealistic worldview (itself idealized) inherited from Uncle Ernst is not an alternative to modernity, but rather an aspect of its development. Of course, Forster embraces his own idealism - Paul Peppis argues that "Forster's national allegories function in two ways: as parables of Englishness enlivened and as fantasies of England reconciled" (47). Forster suggests that the Schlegels must 'only connect' with the imperial Wilcoxes and lower (though not working) class Basts, and such a connection has taken place by the end of the novel. The architectural spaces in the novel however, particularly Howards End, mark this connection as compromised, in that the progress of a new bourgeoisie is facilitated by the house so as to lay the foundations for a future repetition of the crisis of authenticity and modernization that the novel stages and attempts to resolve.

Nostalgia in itself is not, of course, a uniquely modernist phenomenon. Nevertheless, Elizabeth Outka writes of a "sense in the early twentieth century that" despite the myriad literary approaches to it, "nostalgia was at best a distraction and at worst a dangerous mask for serious problems" such as the rise of commercial culture, environmental degradation and so on (255).

\footnotetext{
${ }^{15}$ As Marshall Berman writes, "[t]o be modern is to live a life of paradox and contradiction ... to be both revolutionary and conservative" (13-14).
} 
The fact that nostalgia is compromised ${ }^{16}$ and co-opted for ideological purposes is not unique to the early $20^{\text {th }}$ century, but as John J. Su argues, the role of nostalgia in Howards End in mediating experience has been supplanted by the mechanization of everyday life, and that it has been "redeployed ... as a response to ... the relative incapacity of individuals to interpret their world reliably" (206). Nostalgia here, then, is the is more than the simple nostalgia for the always-lost past of Albion; instead it is yet another 'space' of mediation where the problematics of modern life can be taken up from a new, oblique angle. Nostalgia, like architecture in the novel is a traditional, historically omnipresent concept that is mechanized, put to new use in order to 'embody' - so to speak - modernity in a fashion that covers and compensates for the insufficiency of the form of the novel.

All this presents us with an ideological corollary to the failed monumentality of the house in the novel. Idealism and nostalgia function as conceptual 'mediating textures' within the novel, taking up and accentuating the formal function that the monument holds in the novel. However, Forster notably gives idealism and nostalgia a satirical treatment that the spaces in the novel do not receive: Margaret incorrectly recalls Ernst's line about the fascination with bigness, asserting that one thousand square miles (and not the original million) are not the same as heaven. The Schlegel sisters, in a more pronounced example, encounter the shortcomings of their own idealism in a game where the attendees of a dinner party must collectively resolve how a fictional dying millionaire will allocate her fortune in her will. Over the course of the night,

\footnotetext{
${ }^{16}$ Randall Stevenson identifies in Orwell - working in the 1930s - an approach that points out "the potentially artificial, constructed nature of regret for the Edwardian period, even while also emphasizing genuine reason for it" (134). The simultaneous awareness of nostalgia's rationality and falsity marks it as a function of broader "ideological fantasy" that constitutes the social reality itself (Zizek 34). Nostalgia's position as a neutral carrier here opens it up for being repurposed by Forster, as Su argues.
} 
Margaret variously tries to convince the party to use the money to help "a few human beings [and] see how, under present conditions, they could be made happier" (93). One of these human beings, of course, figures in her mind as Leonard. No one is interested in Margaret's imagination, however, as the imperative to 'only connect' is ignored "[b]etween the idealists and the political economists" thanks to whom "Margaret had a bad time." The party culminates when the last will and testament of the millionaire is read "in which she left the whole of her fortune to the Chancellor of the Exchequer. Then she died" (94). More than foregrounding the importance of inheritance in the novel, this scene allows Forster to criticize the Schlegel's nostalgic cosmopolitan idealism in a way that aligns it with the nostalgized and ideologically constructed spaces in the novel. It follows from this critique that, with their roots in conceptions of the past, both philosophical idealism and nationalist conceptions of space are epiphenomena of modernity more broadly; the famous German idealism that is the inheritance of the Schlegel sisters is supplemented and undermined by the English preoccupation with space and place. As a monument that has failed in traditional terms, the house cannot contain the new Englishness that is to be fostered within its walls, as both the house and its ideological contents are constructed on the same faulty foundation.

\section{The Monumental Novel}

The focus on architecture that we've maintained thus far provides us with a significant, but incomplete grasp of how monumentality operates in relation to Howards End and how exactly this configuration relates to modernism at large; how, that is to say, the novel lives up to 
or even surpasses Virginia Woolf's claim that "it is an important if unsatisfactory piece of work which may well be the prelude to something as large but less anxious" (395). The best place to begin in this assessment is to take stock of the position of Howards End, as Forster understood it, in relation to the broader literary heritage in which he was writing. Much like the introduction of 'monumental signs' that Lefebvre identifies in the process of adorning a house as a monument, Forster takes steps to adorn Howards End with the 'signs' of a literary novel. Allusion abounds: Wickham Place, as we've established, is named after Jane Austen's infamous Wickham, from Pride and Prejudice. Of course, there is more to this than the simple practice of literary allusion; instead it points toward the way in which Forster populates his novel with spaces much the same way as Austen (and most other authors) populate their novels with characters. Pemberley in Pride and Prejudice stages a drama of marriage plots and character interactions, whereas in Howards End we find a drama of spaces staged in the internal subjectivity of Margaret Schlegel, taking a position akin to the nascent 'camera eye' of modernist subjectivity, best expressed in Christopher Isherwood's late modernist Goodbye to Berlin. ${ }^{17}$ Forster acknowledges the necessity of a situated eye in his novel when the burial of Ruth Wilcox is followed by "silence absolute. The cottage that abutted on the churchyard was empty, and no other house stood near. Hour after hour the scene of the interment remained without an eye to witness it" (66). The ethereal Ruth is in death marked by an absence of the roving, subjectivized eye, and Margaret, as her

\footnotetext{
${ }^{17}$ Isherwood's Goodbye to Berlin famously opens thus: "I am a camera with its shutter open, quite passive, recording, not thinking ... Some day, all this will have to be developed, carefully printed, fixed" (1). The neutrality of the viewing eye in modernism is of course a fantasy of sorts, but the autonomy of the eye persists and is important insofar as in both Forster and Isherwood, the emphasis of the eye's neutrality and autonomy serves to alienate and critique implicitly the concept of objectivity as such. The disintegration of the objective eye leaves a vacuum of determination wherein the monument takes new precedence.
} 
replacement, fills the role of viewer, the role of subjective space for the interplay of architectural spaces - Ruth's mystery is supplanted by Margaret's worldly pragmatism

Beyond the confines of Howards End, the novel in general lends itself readily to a genealogy that produces the monumental, symptomal modernist novel. In one of the most influential early theorizations of the novel, Georg Lukacs writes that "The outward form of the novel is essentially biographical. The fluctuation between a conceptual system which can never completely capture life and a life complex which can never attain completeness because completeness is immanently utopian, can be objectivised only in that organic quality which is the aim of biography" (77). Lukacs famously considered the realist novel of the nineteenth century to be the novel par excellence, and as such his emphasis on biography is unsurprising. Even here, however, we find an operative gap that constitutes his realist, 'ideal' novel: everyday life, itself constituted by the impossibility of utopian 'immanent completeness' is separated from a 'conceptual system' that similarly fails to attain completeness in its use of literary representation of life. The insufficiency of literary representation is manifested at two levels: first in its inherent incapability to completely re-present the 'reality' from which it draws its inspiration and then in the very lack in that 'reality' that renders it necessarily incomplete. That is to say that even if a mode of literary or aesthetic representation did exist that could capture all around it, it would still be flawed and incomplete precisely because the 'all' that surrounds it is itself incomplete. The realist novel, for Lukacs then bridges the gap between these two incomplete spheres with 'biographical form.' The key to biographical form is not in the genre-specific rules of biography 
but in its faithfulness to the storytelling impulse, or the common recounting of everyday life. ${ }^{18}$ This form, which Lukacs calls 'organic' is indeed lifelike in a sense. It bridges the gap between life and representation through a recourse to the everyday merger of life and representation more than being a simple outgrowth of everyday life and discourse (which, channeled through the veins of power that so often accompany literary production, produced the Epic forms that Lukacs juxtaposes with the novel), the realist novel is a specifically modern approach to representation. It is in itself a reflection on the gap between representation and life that imposes a norm of 'objectivity' on representation in order to cover that gap.

How is the modernist novel distinct from this, then? As we've seen, the modernist novel (beginning with Forster) reacts to the presumption of an organic mode of representation in realism by supplanting the recourse to biography with a recourse to spatial forms. Such distinctions must necessarily be fundamental - Forster was aware of the well-known novel's acquisitive, polymorphous nature. In his 1927 lecture Aspects of the Novel Forster identifies the novel as "most distinctly one of the moister areas of literature — irrigated by a hundred rills and

18 Brecht, one of Lukacs's greatest critics, took a different (anti-realist, modernist) approach to the traditional practice of 'relating' everyday life in his concept of 'epic theatre.' In "The Street Scene" Brecht elaborates on the acting methods of epic theatre, wherein method acting was rejected and replaced by the simple relation of the scene to the audience in a fashion akin to a witness explaining a car accident to someone who hadn't seen it. Brecht claimed that such theatre allowed for a "return to the very simplest 'natural' theatre, a social enterprise whose origins, means and ends are practical and earthly" (126). Epic theatre was in this way meant to produce a revolutionary alienation-effect wherein the audience would be estranged from the accepted norms of everyday life within capitalist modernity. A vocal critic of Lukacs's commitment to realism - he saw Lukacs as stuck in a nineteenth century where "the bourgeoisie was still a progressive class" (Benjamin, Conversations with Brecht, $86)$ - Brecht would not accept a correlation between realism's practice and his epic theatre. Though their approaches are similar, the important and helpful feature by which we can distinguish the realist novel from epic theatre is in its use of objectivity and its assumption of an organic stance in relation to its subject matter. Acting in epic theatre instead takes an alienated, self-consciously (as opposed to unconsciously as in the case of the realist novel) political stance toward the way in which its subject matter is related. We could posit, tangentially, that the modernism of Brecht can be located here, in the attitude toward form as a means to an end instead of an end in itself. 
occasionally degenerating into a swamp" (5). What immediately jumps out in Forster's metaphor are the echoes of the imagery of flowing and stagnant water in Howards End. The novel for Forster is characterized by the same variability and murkiness that is to be found in London, which in Howards End is a particularly 'modern' metropolis. Forster acknowledges the propensity of the novel to incorporate other forms, sympathizing with the resentment for the form felt by poets and historians who "find themselves in it by accident" (5). Forster's concept of the novel is one of a form that grows and develops "when it acquires new sensitiveness; and the novel's success lies in its own sensitiveness, not in the success of its subject-matter" (20). The novelist is, in Forster's theorization, a transhistorical subject: "All through history writers while writing have felt more or less the same" (21), and as such the development of the novel is determined by the author-subject's disposition toward the 'sensitiveness' of the novel or, to put it another way, the formal means by which the novelist distinguishes their particular iteration of "the novel - that spongy tract ... prose of a certain extent which extend[s] so interminably" (23). Forster's recourse to form in Howards End takes advantage of the special generic 'sensitiveness' of the novel and in doing so sets the tone for the modernist novel's metacognitive focus on the very formal sensitivity of the novel form as the site of its 'success' insofar as success can here be equated to the authenticity, or 'truth-effect' of the modernist novel.

\section{The 'Truth-Effect' of Monumental Failure}

It is clear at this point that the failure I've ascribed to Howards End (and Howards End) in its role as the authentic monumental space that Forster sets it up to be is a complex and 
incomplete failure. The eponymous house is so suffused with the ideologies of English nationalism and imperialism that it is difficult to distinguish the house itself from those significations that Forster attempts to pin to it; as Jason Finch claims, "[ $\mathrm{t}]$ he metaphor of Hertfordshire as the Forsterian literary place . . is further complicated by the fact that Forster in the symbolic meaning he confers on Rooksnest makes the house stand for the whole country as well as being itself, with its own particularity and uniqueness" (353). While the key to the 'failure' of Howards End as a monumental space is its complicated and incomplete production of the sort of cohesion and consensus of social practice that Lefebvre identifies as a key component of monumentality, its inherent multiplicity as a signifier - it carries all of the symbolism that Finch identifies with the real (and imagined) Hertfordshire along with its connotations within the text - destabilizes it as a monument. This instability stems from the house's origins as a pastiche that produces an ambiance of a social life completely reliant on nostalgia for a past that, if it ever actually existed, predates even those architectural forms on which the house is based. Importantly, nostalgia here is both literary and spatial; Ian Baucom, drawing on Raymond Williams asserts that "English writing . . . has been obsessively concerned with the attempts to compose an image of English identity through a negotiation of the melancholy discourses of nostalgia . . . England is always already lost, wounded, or vanishing” (176). Similarly, Jon Hegglund explains that a "[1]iterary regionalism" preoccupied with "places, landscapes, and dialects ... seen in some opposition to or distinction from metropolitan urban centers" is, along with geographic realism, suggested in the novel as the solution to Margaret's anxieties (60). Margaret's thinking, as detailed above, contains the dissonance in this binary, however: she longs 
for the English home even while she expresses admiration for the machinery of the modern city and England's empire. These two spaces, despite their differences in scope and organization, share their origin in the embrace of capitalism and nationalism that lies at the heart of the English identity Forster attempts to graft onto Howards End, and thus that embrace is the subject of Margaret's desire just as much as, if not more than, the house itself.

Ultimately, the failure of the house as a monument could be better understood as a new or limited success in terms more fundamental than the narrative success in the novel that takes the form of the final alliance between the Schlegels, Wilcoxes and Basts. This success-as-failure does in fact speak to the historical moment of modernization as a process of disjuncture produced by a lag between material reality and the cultural understandings surrounding it. Aesthetically, the novel enacts this same lag by plumbing the standards and expectations of realism in order to articulate modernist concerns. What we're left with then is a new sort of relationship between the monument and social space - the gap between form and the social is bridged by a new monumentality that is uniquely modern and centered around the disjuncture between social life and architectural space. It achieves a 'truth-effect' - an authenticity precisely in its articulation of the non-identity between the two. Similarly, the modernism of Howards End is modernist in its enactment of the disjuncture between the 'reality' that realism sought to represent and the novel itself, written in a realist vein, which nevertheless stages a new kind of monumentality that calls that correspondence into question. Russian modernist artist El Lissitzky wrote in 1919, nine years after the publication of Howards End and with modernism in the ascendancy that literature, in the form of "the book is now everything . . . it has become what 
Weihl 42

the cathedral with its frescoes and stained glass ... used to be ... The book has become the monument of the present" (qtd. in Gough 102). The situation of Howards End as a house reflects modern life insofar as it is a monument that cannot produce its attendant social fabric precisely because the social fabric from whence it grew is always already shattered, unrecognizable when compared to the social spaces of traditional monuments. Howards End is a monument to modern life in the same way, drawing on styles that were, at the time it was written, drifting into obsolescence in order to parse, incompletely, a social and economic landscape for which they were unsuited.

In Howards End, English national identity is ultimately undermined by that which produces it - the Wilcoxes must enter the colonies to attain and maintain their status, Leonard Bast is driven to his death by his pursuit of 'true living,' and even the refined Schlegels with their desire for 'connection,' are half-German and in any case under the spell of an idealism rooted in the same nostalgia with which Howards End is imbued. Though the novel suggests that if these disparate characters were only able to connect that the social fabric could be repaired, it simultaneously uncovers the fact that both Howards End and England are constructions of capitalism and colonialism that assume an authentic, rooted, premodern core that was never actually present; as Margaret tells Helen as they sit outside of Howards End near the novel's conclusion: "very early in the morning I feel that our house is the future as well as the past" (Forster 240). At the broadest level, the modernism that the novel practices in bridging the gap between form and content unites the Modernist future of the novel and its Realist past. Furthermore, in the context of the narrative, Margaret's dream begs the question - given the 
global scope of the urban advancement that they acknowledge, is Howards End dreamed of as England's future, or the future of the world? Does Margaret see her ideal of domestic life as the ultimate export of Britain's colonial system? The answers, of course, are immaterial; England and Forster's English both look to the house as a monument and an alternative to the urban wasteland of London - a role that Howards End cannot fill due to its origins in the same mode of production as the city that will ultimately consume it. The house, like those who inhabit it and the money that built, purchased and maintained it, will be subsumed by the inexorable advance of capital that liquefies all - from the waves of peasants breaking against the hard rocks of the metropolis, to the populations and resources of distant colonies, to the fountain-like tenements of London, to the estuary of Wickham Place.

\section{The Last September: Beyond Howards End}

It would be incorrect to assume that the implication of Howards End's gap between form and content was filled properly and completely in later modernist texts that were more rigorous and adventurous in their formal experimentation. The 'recourse to form' that we've identified in Forster's novel - which takes the shape of the house - is replicated throughout modernism in different, often not exclusively spatial forms: Ulysses, of course, is famously given literary form by The Odyssey while simultaneously drawing on the spatial form of the city of Dublin. Nevertheless, the house persists as a form-giving element in the modernist novel even as formal experimentation accelerates. Here, we'll briefly extend the understanding that we've established of how the English home operates within Howards End and use it to examine a novel that 
approaches modernity in a distinct manner while still refracting its approach through the house. Elizabeth Bowen's The Last September centers around a country house that serves as the hub of the novel's symbolic economy while simultaneously standing as a cipher for the concerns that the novel takes up. The Last September positions its house as a site of tension between internal social and domestic determination and external political determination. The Irish War of Independence reenacts the gap between form and content that is bridged by the house via the emphasis that it places on the compromised colonial situation of its cast of Anglo-Irish settler colonists. As I will demonstrate, the settler-colonist landowning class, the Ascendancy, take up a 'third position' covering the gap between the English and the Irish - between colonizer and colonized - and in doing so take a place alongside the house (itself both a political and social/cultural sign that does similar work to that done by the houses in Howards End) in the novel's attempt to symbolically resolve the gap between its form and its content.

In her book, Elizabeth Bowen: The Shadow Across the Page, Maud Ellmann asserts quite rightly - that the "Big House in Bowen's work" demonstrates how "architecture shapes the mentality of its inhabitants, determining the way that they perceive the world" (41). While this is certainly the case, another more obvious form of determination is enforced by the architecture of the Big House and its environs in The Last September: the determination of movement, daily life and spatial practices. The psychological depths that Bowen explores through the novel surely are reproduced in the architecture; however, I want to expand and reimagine this critical move from the house to the subjectivities of its inhabitants and widen its scope to include a consideration of the broader colonial space within which the house (and, consequently, its inhabitants) is 
positioned. By way of this (outward) move to the colonial, I hope to demonstrate how the form / content gap in The Last September - published in 1927 and more formally experimental than Howards End - is bridged by a recourse not only to the form of the house but furthermore by a recourse to the ideological configuration of the colonial itself. In order to do this, I apply Michel de Certeau's concepts of 'strategies and tactics' to The Last September. The novel's setting, in and around the Anglo-Irish Big House, allows me to juxtapose both the gendered spatial practices of its inhabitants and the larger struggle for decolonization - the Irish War of Independence during which the novel is set. I read for strategies and tactics simultaneously in two different, but interconnected spaces: the big house and the larger colonial space itself, in order to better understand the 'third position' of the Anglo-Irish gentry in The Last September in the spatial terms that this positioning implies. The novel, I claim, posits a 'mediating texture' between the two positions in colonial relations that mirrors the mediating texture of the house.

Such a reading demands, of course, that I provide a more complete outline of Certeau's conceptions of strategies and tactics and their particular relationship to my argument. In The Practice of Everyday Life, Certeau defines "a strategy" as "the calculation (or manipulation) of power relationships that ... postulates a place that can be delimited as its own and serve as the base from which relations with an exteriority . . can be managed" (35-36). The place that projects power in my configuration is, of course, the Big House. Against strategies, Certeau positions a tactic as "a calculated action determined by the absence of a proper locus . . . [it] is determined by the absence of power just as a strategy is organized by the postulation of power" (38). Strategies and tactics, then, provide us with two different and conjoined ways to conceive 
of the power dynamics of place and the structural implications of the arrangement and demarcation of spaces. The Big House, particularly in The Last September, plays out these dynamics in a number of ways that are cumulatively significant in our understanding of the novel in terms of how it conceptualizes the relationship between the personal and the political and how these relationships are mediated and articulated in spatial terms.

Of course, the space in the novel is governed by more than just physical barriers; Jed Esty calls The Last September a colonial novel of manners (252), and this characterization is indicative of the importance of social standards in the novel. Notably, we see these manners and social practice expressed in terms of movement through delineated spaces: "Do you dance on the avenue?' said Mr. Montmorency to Lois. 'Only once, for a bet. I and a man called Mr. Lesworth danced to the white gate, and the man that we had the bet with walked after us carrying the gramophone. But naturally, I don't as a rule."' (27). Dancing is most obviously is associated with the practices of courtship in which Lois is expected to be indulging. Instead of participating in courtship rituals in a manner that is expected of her, however, Lois upsets these expectations in a mildly scandalous manner. The expectations of courtship and socialization serve here as ideological strategies, and as such Lois tactically deploys unorthodox dancing as a subversion of the social norms that she feels compelled to resist. This resistance is not undertaken explicitly but rather with what Certeau calls the "rhetoric of walking" wherein one moves at will among the options available that make up the "geometrical space of urbanists and architects [which] seem to have the status of the 'proper meaning' constructed by grammarians and linguists" (100). The 
strategy of social standards is subverted and disobeyed by Lois's tactical dancing in an abstracted and symbolic manner that would not be possible in speech.

The silence that obtains throughout the novel underscores the insufficiency of speech in the problems faced not only by Lois, but by her family and the wider population of Anglo-Irish gentry. The pervasive silence with which the Naylors, Farquars and Montmorencies confront The Irish War of Independence - Lois insists that Marda swear to never speak of their encounter with an Irishman in an abandoned barn who nearly shoots them (Bowen 183) - is a testament to the imminent collapse of the strategically arranged power structure of the Ireland of the Union. To elaborate on the linguistic turn gestured toward above, it's important to note that for Certeau, strategy aligns with Saussure's concept of langue (the language system) and tactics align with parole (speech acts) (32). Within the larger langue-like system of Anglo-Irish society, the speech acts of gossip take on a tactical tone: as the Anglo-Irish matriarch of Danielstown (who, tellingly, is Lois's childless Aunt) Lady Naylor declares, "I've always turned my face against gossip, especially these days ... It's a very great danger, I think, to the life of this country" (78). She recognizes and is unsettled by the politicality of gossip, of those resistive and disruptive speech acts which upset the stability of the ideally depoliticized social circles within which Lady Naylor and the Anglo-Irish gentry see themselves moving.

Central to first the establishment of Anglo-Irish power historically and then consequently to the undermining of it in The Last September is the Big House itself. Danielstown - based at least in some part on the author's childhood home of Bowen's Court - dominates ${ }^{19}$ the narrative

\footnotetext{
19 Its polyvalence as a symbol - at once looming, rotting and microscopic - marks it as even more deterministic
} and monumental precisely in its adaptability as a sign. 
much as it dominates and determines the lives of its inhabitants, and as much as it historically dominated the landscape; devoid of the bourgeoisification that defines Howards End or Wickham Place, it is properly monumental, more residence than housing. Danielstown is repeatedly turned to as a point of consistency in the midst of the narrative: "The sky shone, whiter than glass ... The house was highest of all with toppling imminence, like a cliff" (36). The centrality of the Big House to the establishment of new enclosures during the settlement of Ireland by the English historically rooted its strategic position in Ireland. Its strategic and deterministic position within the lives of Lois, her family and friends is made clear by Bowen and is demonstrated to be definitive for the characters - in the first sentence of the novel, "the household" is "brought ... out in excitement on the steps" by the arrival of the Montmorencies (3), establishing a metonymic relationship between the house and its occupants. At the same time, however, the house is a source of vexation even for Lady Naylor, who "moved around the Blue Room, nodded out of a window to someone distant coming out from some trees—-she could never learn how one vanishes in the dark of a house" (17). The efficacy of the house as the 'place' in which a strategy is rooted, from which it projects its authority and determines an exteriority is complicated by the novel in terms of the simultaneous liminality that accompanies the imposition of boundaries by the house. The political turmoil of Ireland - which, as we will see later, can be figured in terms of its positioning within a larger imperial strategy - is the source of this instability. The formal immanence of the Big House belies the textural mediation facilitated the positions enforced by imperialism. 
Weihl 49

The anxiety surrounding the contamination of the Anglo-Irish sphere by the common Irish $^{20}$ is manifested in concerns about the susceptibility of the house to infiltration by ants: Laurence, looking resentfully around for somewhere to sit—she had taken the only cushion—said: "I suppose you think ants cannot run up your legs if you cannot see them?" .. . "The ants are asleep" [Lady Naylor] said, "they disappear into the cracks of the steps. They don't bite either; but the idea is horrid." (36)

Here we can see the link between social practice and larger political anxieties as cousin Laurence, whose academic pursuits and antisocial tendency evince a general dissatisfaction with the social sphere of Anglo-Irish society, is unable to find a place to sit down. His inability to navigate the social situation in this most fundamental and simple way is not merely a personal fault of his, but rather a structurally enforced problem, as there isn't a cushion available to him. Simultaneous with his social struggles, Laurence discusses the ants - a heavy-handed metaphor for anxieties about class contamination. What is most notable, however, is that the stairs are the site of infestation, not the house itself; the steps are at once a site of repeated social gatherings throughout the novel and a very literal point of liminality in the house where boundaries can be crossed, emphasizing both the house itself and the social sphere being marked here as particular points of anxiety about class contamination.

The enforcement of boundaries takes place outside the bounds of the house as well, of course. The larger question at stake over the course of novel - the question of Irish independence

20 As Jed Esty notes, the English are an differently problematic source of contamination, representing "rank middle-class materialism" (a la the Wilcoxes) that is no more amenable to the Anglo-Irish sensibility than the Catholic peasants of the countryside (260). The 'third position' of the Anglo-Irish settler colonists that Esty gestures toward is important for our discussion and will be explored further later. 
- can be understood, like problems of the social sphere, in spatial terms through strategies and tactics. Indeed, as in the passage above, we can find the larger colonial question as a kernel comprised by questions of socialization: Lady Naylor remarks that the English "are kindness itself once they have 'placed' one" (196). To be 'placed' here takes on multiple valences, meaning both to be placed socially and to be placed geographically by the empire. In fact, the class and geographic markers provided by accents unify these two kinds of placement and furthermore demonstrate the potential for slippage and overlap between strategies of social practice and strategies of empire. Indeed, the cultural and national origins of the Big House very much 'placed' it, as Maud Ellmann explains:

Reared in stone, the Big Houses embodied the 'European idea' of civilisation, the sweetness and gentleness of classical form and flowering lawns masking the violence that brought them into being. Each of these 'house islands,' with its intense, centripetal life, placed a 'frame' around the lives of its inhabitants, providing an aesthetic in default of rootedness. Within these frames, the Anglo-Irish lived like only children, isolated from the native population by religion, nationality, and social class - 'singular, independent and secretive.' (43)

I quote Ellmann at length because she so aptly juxtaposes and synthesizes the cultural significance of the Big House in tandem with its political significance in Ireland. The wider political placement of the Big House sees it caught in multiple strategic fields; it simultaneously arranges the exterior of the countryside as a dominated space while comprising the dominated space of the empire in which it is positioned. 
This 'third position' - the position of the mediating texture - is crucial for our discussion, as it clarifies the specific predicament of the Anglo-Irish Ascendency as a settler class. Alan Lawson, writing about Australian settler culture, conceptualizes the third position - settlers are neither of the empire nor of the native land - in spatial terms, framing it as an 'anxious proximity.' For Lawson, the proximity is understood in straightforward spatial terms while also being conceived of in terms of the use of the ideologemes that narrativize settler anxieties and resolve the uncanny qualities of settler colonialism, exemplified again in spatial terms: Lawson, drawing from Ken Gelder and Jane M. Jacobs, defines the postcolonial uncanny as the habitation of the same place by two groups that at the same time inhabit "places which are not the same" (1214). This uncanny cohabitation is a superspatial expression of the "infinity" that Jameson suggests as characteristic of modernist representations of imperialism - this, he writes, is expressed in Forster when "common-sense space perception is disrupted by the emergence here and there of a dawning sense of the non-perceptual spatial totality" (160). The Last September is devoid of expressions of infinity comparable to Howards End due to it being set in the colonial sphere - nebulous and ephemeral, the novel takes place within the colonial infinite, and the Big House is the only monumental strong point, or spatial nexus within the infinite. The infinite is expressed in the social situation of the Ascendancy as well. In his reading of The Last September, Jed Esty places the Anglo-Irish in the third position, characterizing them as "floating above and trapped between" the Irish and the English (260). The strategic field exerted by the native population, rooted in their original claim to the land, overlaps with the strategic field of the empire, placing the settler-colonists in two different exteriors; this doubling is again productive 
of the uncanny, which we can credit with the gothic character that Esty assigns to the novel, and to the colonial novel more broadly (257). Consequently, then, we can think of the Big House as a tactical deployment by the Ascendency when faced with their third position, and their insular emphasis on banal socialization even in the midst of a war as a form of tactics wherein the two strategic fields imposed by the combatants (note here the very real strategy involved in conducting war) are "terrain imposed . . . and organized by the law of a foreign power" within which the Anglo-Irish can only "play" (Certeau 37).

That play finds its iteration in movement and conceptions of space, of course, with social practices of dances and visitation serving as the quintessential examples. Even within the house and its environs, repeated peregrinations through the garden serve as an outlet for a pervasive anxiety. Just as the imposition of a strategy of settler colonization on the Irish countryside is executed through the development of property enclosures and the accompanying Big Houses, the temporal rituals of Anglo-Irish culture in The Last September speak to the "triumph of space over time" (Certeau 36) that characterizes strategy, wherein the movements of the Anglo-Irish are mapped out and built into everyday life. The break down of Ascendency strategy is of course brought on by the war, and is evinced in the episode where Marda is shot as she and Lois walk abroad, the shooter telling them "It is time . . yourselves gave up walking. If yez have nothing better to do, yez had better keep within the house while y'have it" (181). These limitations on movement are highlighted differentially in Gerald, the English soldier who does "not care for parties; he went everywhere, he liked to go out every day" (45). Gerald's strategic superiority the empire clearly predominates over the settler culture in political terms - allows him a freedom 
of movement that emphasizes the tactical nature of the social practices of the Ascendency. This 'tacticality' should not obscure the coterminous strategic role of Anglo-Irish society and the spaces in which it is staged and practiced, but should rather emphasize the polyvalence of strategies and tactics in the novel and in the larger geopolitical, social and personal moments that Bowen is attempting to depict.

This all raises the question, however, of whether we could then conceive of the larger strategy of Anglo-Irish culture as being an imposition on Ireland as a whole or rather an imposition on the Anglo-Irish themselves. The reality, of course, is that this is true in both senses. Jed Esty's conclusion about The Last September that the "structural contradictions of settler colonialism and ... postcolonial nationalism" are encoded in the novel's staging of Lois Farquar's "frozen, virginal state" (259) demonstrates how these dual impositions bleed into one another, and there is further mixing of the personal, the social, the architectural, the geographic and the political throughout that speaks to the infectiousness of spatialization in the novel and in the larger historical moment. Lois reflects to herself that without love, "one never knows quite where one is" (275), and conceives of her emotional economy in spatial terms. Furthermore, when asked his opinion on the political situation in Ireland, Laurence can only articulate it by saying that "Things ... Seem to be closing in . . . Rolling up rather." (28). In his later conversation with Gerald, Laurence again reverts to a spatial metaphor for politics, thinking of civilization as "a rather perplexing system of niceties . . . an exact and delicate interrelation of stresses between being and being, like crossing arches" (133). Here again, social norms, politics and space all intersect; crucially, though, these explicit spatializations are expressed by the 
younger characters in the novel, particularly Lois and Laurence, ${ }^{21}$ whose angst and dissatisfaction lead them to an understanding, on some level, of the spatialization enforced by strategy.

It is appropriate that a novel that ends in the immolation of the house by the Irish Republicans should be so preoccupied with the overlap and cross-contamination of the personal and the political. The action of the novel - the burning of the house, Gerald's death and its convenience for Lady Naylor - certainly explores this intersection, and as I've attempted to demonstrate, the thematics of the novel similarly express this sort of overlap. The ultimate expression of this is the house, Danielstown, itself; the Big House can be understood in this context as what Certeau calls "a reversible sign" that "transforms the temporal articulation of places into a spatial sequence of points" (35). The Big House in The Last September undertakes the transformation of time into space in its arrangement of everyday life and in its enforcement of social norms, which, like the steps of a dance, so often take the form of 'trajectories.' Conversely, the house undertakes the reverse transformation, transforming space into time by signifying, through its architectural space and its enclosure of property, the historical fact of colonialism. It ultimately goes up in flames, as Maud Ellmann notes, having been caught between the history of colonialism and the future of the Irish Republic (42). We see, then, the Big House as caught between both spatial strategies and temporal narratives that render its third position untenable and precipitate its fiery end.

21 Laurence is described by Lois to Gerald as "too modern" for not caring "about girls at all” (268); Lois's wavering indifference toward men marks her as equally modern according to her own standards. 


\section{Conclusion: Mediating Textures}

In The Last September we find a mutated form of the monumentality that characterizes Howards End - it takes shape not just in the form of the Big House but, crucially, in the interplay of positions within the colonial texture, manifested as strategies and tactics. What this suggests is that modernism's deployment of a 'mediating texture' in a third position in order to resolve the form / content division is not a practice limited entirely to architecture, and instead can be rearticulated in a variety of orbiting configurations that supplement the architectural mediation. The mediating textures could then be best conceived of as an ideologeme, Fredric Jameson's formulation of "a historically determinate conceptual or semic complex which can project itself variously in the form of a 'value system' or 'philosophical concept,' or in the form of a protonarrative, a private or collective narrative fantasy" (115). The recourse to form enacted by a mediating texture within the modernist novel - to return to Howards End - utilizes the architectural form of the house-as-pastiche ${ }^{22}$ as a projection of the semic problem of literary representation of modern life. As Jameson says of the Romance, "form may then be understood as an "imaginary 'solution' to [a] real contradiction, a symbolic answer" to a political or social problem. That problem in our argument has then been modernization itself: the mediating texture in modernism is a literary, symbolic resolution meant to cover the gap in the possibilities of representation introduced in a unique way by the accelerated and revolutionary modernization of the late nineteenth and early twentieth centuries. With Lukacs's form of realist biography

22 Jameson's definition of pastiche as a "neutral mimicry" or "blank parody" wherein image and tone are reproduced without any ironic intent (17). The effect of this, as Jameson establishes, is a contamination of modernist 'high individual style' through the recourse to dead cultural modes as a means of communication. The antipathy between the pastiche-house in Howards End and the novel's modernist aims is yet another marker of the insufficiency and failure of the monumentality that it presents. 
rendered newly insufficient, the recourse to form as a mediating texture within Howards End produced a more apt insufficiency that succeeded precisely in its monumental failure.

Ultimately, the failure of the monumental house in Howards End is a formal complex that replicates the formal insufficiency of the modernist aesthetics that it constitutes. It covers the gap between form and content and in doing so constitutes the aesthetic relationship between the two that the novel takes up. Similarly, The Last September utilizes the Big House as a stage for the political drama surrounding the Anglo-Irish Ascendancy. The crumbling hegemony of Danielstown is at once a direct metaphor for the disintegration of the colonial order in Ireland and at the same time a form that, like Howards End, reproduces the function of the novel precisely in its failure: it desperately attempts to reign in and determine the social space and narratives that surround it, just as The Last September as modernist novel shifts and mutates formally to capture the myriad anxieties of modern life. The identity shared by the two houses in their shared functions as ideologemes is crystallized in their disparate fates. Howards End is ultimately inherited by a tentative new compromise between the different classes in the novel, which closes with a scene of the house glowing cautiously with new life. Danielstown, on the other hand, is torched in the night by Irish revolutionaries - its aged owners watch it burn while the disaffected youths who populate the novel pursue their lives elsewhere. These two conclusions have more in common than they initially appear to, as in both the houses serve as ciphers, facilitators, empty vessels for the social situations that the novels express. They cover for and organize the always-already failed task of representation and are altered substantially in the process, whether occupied or immolated. As monuments, the houses are "the future as well as 
the past" (Forster 240) insofar as they structure the present just as they structure the space around them. The necessary incompleteness of this structure - the present can never be grasped, the space can never totally be conceived - is the necessary incompleteness of the representational project of modernism; monumental failure is its constitutive core. 


\section{Works Cited}

Bachelard, Gaston. The Poetics of Space. Trans. Maria Jolas. Boston: Beacon Press, 1994. Print. Baucom, Ian. Out of Place. Princeton, NJ: Princeton U P, 1999. Print.

Berman, Marshall. All That is Solid Melts Into Air: The Experience of Modernity. New York: Simon \& Schuster, 1982. Print

Bhabha, Homi. "Signs Taken for Wonders: Questions of Ambivalence and Authority under a Tree outside Delhi, May 1817." Critical Inquiry 12.1 (1985): 144-65. Print.

Bradshaw, David. "Howards End.” The Cambridge Companion to E.M. Forster. Ed. David Bradshaw. New York: Cambridge U P, 2007. 151-172. Print.

Benjamin, Walter. "Conversations with Brecht." Aesthetics and Politics. Ed. Ronald Taylor. London: Verso, 1980. 86-99. Print.

Benjamin, Walter. "The Work of Art in the Age of Mechanical Reproduction." Illuminations. Ed. Hannah Arendt. New York: Schocken Books, 2007. 217-252. Print.

Bowen, Elizabeth. The Last September. New York: Anchor Books, 2000. Print.

Brecht, Bertolt. "The Street Scene: A Basic Model for Epic Theatre.” Brecht on Theatre: The Development of an Aesthetic. Ed. John Willett. New York: Hill and Wang, 1957. 121129. Print.

Certeau, Michel de. The Practice of Everyday Life. Trans. Steven Rendall. Berkeley: U of California P, 1984. Print.

Ellman, Maude. Elizabeth Bowen: The Shadow Across the Page. Edinburgh: U of Edinburgh P, 2003. Print. 
Esty, Jed. "Virgins of Empire: The Last September and the Antidevelopmental Plot." Modern Fiction Studies 53.2 (2007): 257-275. Print.

Felski, Rita. "The Invention of Everyday Life.” Cool Moves 39 (1999): 15-31. Print.

Finch, Jason. E.M. Forster and English Place: A Literary Topography. Turku, Finland: Åbo Akademi University Press.

Forster, E.M. Aspects of the Novel. New York: Harcourt Brace, 1927. Print.

Forster, E. M. Howards End. 1910. Ed. Paul B. Armstrong. Norton Critical Editions. New York: Norton, 1998. 5-244. Print.

"Genius loci." The Dictionary of Human Geography. $5^{\text {th }}$ ed. Web.

Gough, Maria, "New in Print." Léger: Modern Art and the Metropolis. Ed. Anna Vallye. Philadelphia, PA: Philadelphia Museum of Art, 2013. 99-108. Print.

Hegglund, Jon. "Defending the Realm: Domestic Space and Mass Cultural Contamination in Howards End and An Englishman's Home." English Literature in Transition, 1880-1920 40.4 (1997): 398-423. Print.

Hegglund, Jon. World Views. Oxford: Oxford U P, 2012. Print.

Isherwood, Christopher. Berlin Stories. New York: New Directions, 1963. Print.

Jameson, Fredric. "Modernism and Imperialism.” The Modernist Papers. New York: Verso, 2007. Print.

Jameson, Fredric. The Political Unconcious: Narrative as a Socially Symbolic Act. Ithaca, NY: Cornell U P, 1981. Print. 
Jameson, Fredric. Postmodernism, or the Cultural Logic of Late Capitalism. Durham, NC: Duke U P, 1997. Print.

Lawson, Alan. “The Anxious Proximities of Settler (Post)colonial Relations.” Literary Theory: An Anthology. Eds. Julie Rivkin \& Michael Ryan. Malden, MA: Blackwell, 2004. 12101223. Print.

Lefebvre, Henri. The Production of Space. Trans. Donald Nicholson-Smith. Maiden, MA: Blackwell, 1991. Print.

Lukacs, Georg. The Theory of the Novel.Trans Anna Bostock. Cambridge, MA: MIT Press, 1974. Print.

Medalie, David. E.M. Forster's Modernism. London: Palgrave Macmillan, 2002. Print.

Morey, Peter. "Postcolonial Forster" The Cambridge Companion to E.M. Forster. Ed. David Bradshaw. New York: Cambridge U P, 2007. 254-273. Print.

Outka, Elizabeth. "Afterword: Nostalgia and Modernist Anxiety." Modernism and Nostalgia: Bodies, Locations, Aesthetics. Ed. Tammy Clewell. London: Palgrave Macmillan, 2013. 252-262. Print

Peppis, Paul. "Forster and England.” The Cambridge Companion to E.M. Forster. Ed. David Bradshaw. New York: Cambridge U P, 2007. 47-62. Print.

Rosenbaum, S.P. Edwardian Bloomsbury. New York: St. Martin's, 1994. Print.

Stevenson, Randall. "Remembering the Pleasant Bits: Nostalgia and the Legacies of Modernism." Novel: A Forum on Fiction 43.1 (2010): 132-139. Print. 
Su, John J. "The Beloved Republic: Nostalgia and the Political Aesthetic of E.M. Forster." Modernism and Nostalgia: Bodies, Locations, Aesthetics. Ed. Tammy Clewell. London: Palgrave Macmillan, 2013. 198-215. Print

Trilling, Lionel. E.M. Forster. New York: New Directions, 1971. Print.

Thacker, Andrew. Moving Through Modernity: Space and Geography in Modernism. Manchester: Manchester U P, 2009. Print.

Woolf, Virginia. “The Novels of E.M. Forster.” Howards End. Ed. Paul B. Armstrong. Norton Critical Editions. New York: Norton, 1998. 391-395. Print.

Zizek, Slavoj. The Sublime Object of Ideology. London: Verso, 2008. Print. 